\title{
Effect of Adding Indium on Wetting Behavior, Microstructure and Physical Properties of Tin- Zinc Eutectic Alloy
}

\author{
Abu Bakr El- Bediwi \\ Metal Physics Lab., \\ Physics Department, \\ Faculty of Science, \\ Mansoura University \\ Mansoura, Egypt
}

\author{
Mohammed Munther \\ Jubair \\ Ministry of Education \\ Iraq
}

\author{
Rizk Mostafa Shalaby \\ Metal Physics Lab., \\ Physics Department, \\ Faculty of Science, \\ Mansoura University \\ Mansoura, Egypt
}

\author{
Mustafa Kamal \\ Metal Physics Lab., \\ Physics Department, \\ Faculty of Science, \\ Mansoura University \\ Mansoura, Egypt
}

\begin{abstract}
Effect of adding indium on microstructure, wetting process, thermal, electrical and mechanical properties of tin- zinc eutectic alloy have been investigated. Microstructure (started base line, lattice parameters, unit cell volume, crystal size and the shape of formed crystalline phases) and measured physical properties of tin- zinc eutectic alloy changed after adding different ratio of indium content. A little variation occurred in thermo-graph (Endo-thermal peaks) of $\mathrm{Sn}_{91} \mathrm{Zn}_{9}$ alloy after adding indium. The contact angle, melting temperature and specific heat of $\mathrm{Sn}_{91} \mathrm{Zn}_{9}$ alloy decreased after adding indium content. Also elastic modulus and internal friction values of Sn91Zn9 alloy decreased after adding indium content. But electrical resistivity and Vickers hardness values of Sn91 Zn 9 alloy increased after adding indium content. The SnZn9In5 alloy has adequate properties for solder applications.
\end{abstract}

Key words: tin- zinc eutectic alloy, thermal and mechanical properties, electrical resistivity, wetting process

\section{INTRODUCTION}

Over the past few years the study of lead free solder has become a hot subject. New lead free solder alloy has great attention from researchers around the world. Lead free solders fall into two groups: first has lower melting points and chiefly includes alloys of tin and bismuth. Second is group of alloys, those with higher melting points than tin-lead. The leading choice seems to be a tin-silver-copper alloy. There is a tin-rich ternary eutectic at about $217^{\circ} \mathrm{C}$. These alloys at $30{ }^{\circ} \mathrm{C}$ higher melting point are a challenge to use. Sn-Zn solder alloys are quite capable in terms of mechanical integrity but have poor oxidation and corrosion resistance. Many studies have been made on various alloy system solders based on $\mathrm{Sn}$ such as $\mathrm{SnZn}_{9}, \mathrm{SnAg}_{3.5}$, $\mathrm{SnAg}_{3} \mathrm{Cu}_{0.5}$, etc. as possible replacements $[1,2]$. T. Ohoak et al investigated the dependence of frequency over a range of $0-3 \mathrm{~Hz}$ on Young's modulus and internal friction in $\mathrm{SnZn}_{9}$ and $\mathrm{SnAg}_{3.5}$ eutectic lead free solder alloys [3]. Several researchers [4- 7] operated to improve the properties of $\mathrm{Sn}-\mathrm{Zn}$ lead free alloy by adding small amount of alloying elements such as $\mathrm{Bi}, \mathrm{Cu}, \mathrm{In}, \mathrm{Ag}, \mathrm{Al}, \mathrm{Ga}, \mathrm{Sb}, \mathrm{Cr}, \mathrm{Ni}$, $\mathrm{Ge}$ to develop ternary and even quaternary $\mathrm{Pb}$ free alloys. The microstructures of the tin- zinc- aluminum lead free solder alloys, which prepared from the $\mathrm{Zn}-5 \mathrm{Al}$ master alloy and $\mathrm{Sn}$, using scanning electron microscopy were investigated [8]. The microstructures and mechanical properties of $\mathrm{SnZn}_{8.55} \mathrm{Ag}_{\mathrm{x}} \mathrm{Al}_{0.45} \mathrm{Ga}_{0.5}$ ( $\mathrm{x}=0.5-3$ wt. \%) lead free solder alloys were studied [9]. Small additions of Ag decreased the melting point of the $\mathrm{SnZn}_{8.55} \mathrm{Ag}_{\mathrm{x}} \mathrm{Al}_{0.45} \mathrm{Ga} 0.5$ solder alloys while maintaining the same strength and ductility as the $\mathrm{Sn}_{63} \mathrm{~b}_{37}$ solder alloy. The effects of adding alloying elements such as $\mathrm{Ag}, \mathrm{Al}$, and $\mathrm{Ga}$, on melting temperature, microstructures and mechanical properties of the $\mathrm{SnZn}_{9}$ lead free solder alloy were studied [10]. The results show, SnZn ${ }_{9} \mathrm{Ga}_{0.5}$ alloy has very good UTS and elongation, which are better than both those of the $\mathrm{SnZn}_{9} \mathrm{Ag}_{0.5}$ and $\mathrm{SnZn}_{9} \mathrm{Al}_{0.45}$ alloys. Also effect of adding $\mathrm{Al}$ and $\mathrm{Cu}$ on microstructural and mechanical properties as well as thermal behavior of $\mathrm{SnZn}_{9}$ lead free solder alloy was investigated [11]. The results indicate the microhardness of the $\mathrm{SnZn}_{9} \mathrm{Al}_{0.5}$ alloy was also higher than that of the $\mathrm{SnZn}_{9} \mathrm{Cu}_{0.5}$ alloy. Tin- zinc is desired to have a lead free solder with a melting temperature close to the eutectic temperature of the tin- lead alloy.
Aluminum has a high melting temperature and good electrical conductivity. It may form solid solutions with tin and zinc. . So that, adding aluminum to tin- zinc solder alloy retain the melting point as low as possible but the soldering temperature higher than that eutectic tin- lead alloy. The aim of this work was to investigate the effect of adding different ratio from indium on microstructure, wetting behavior, thermal, electrical and mechanical properties of tin- zinc eutectic lead free solder alloy.

\section{EXPERIMENTAL WORK}

The alloys $\mathrm{Sn}_{91-\mathrm{x}} \mathrm{Zn}_{9} \mathrm{In}_{\mathrm{x}}(\mathrm{X}=0,1,2,3,4$ and 5 wt. \%) which used tin, zinc and indium elements with a high purity, more than $99.95 \%$, were molten in the muffle furnace. The resulting ingots were turned and re-melted several times to increase the homogeneity of the ingots. From these ingots, long ribbons of about 3-5 $\mathrm{mm}$ width and $80 \mu \mathrm{m}$ thickness were prepared as the test samples by directing a stream of molten alloy onto the outer surface of rapidly revolving copper roller with surface velocity $31 \mathrm{~m} / \mathrm{s}$ giving a cooling rate of 3.7 $\times 10^{5} \mathrm{k} / \mathrm{s}$. The samples then cut into convenient shape for the measurements using double knife cuter. Structure of used alloys was performed using an Shimadzu $x$-ray diffractometer (Dx-30, Japan) of $\mathrm{Cu}-\mathrm{K} \alpha$ radiation with $\lambda=1.54056 \AA$ at $45 \mathrm{kV}$ and $35 \mathrm{~mA}$ and $\mathrm{Ni}-$ filter in the angular range $2 \theta$ ranging from 20 to $100^{\circ}$ in continuous mode with a scan speed $5 \mathrm{deg} / \mathrm{min}$. Scanning electron microscope JEOL JSM-6510LV, Japan was used to study microstructure of used samples. The melting endotherms of used alloys were obtained using a SDT Q600 V20.9 Build 20 instrument. A digital Vickers microhardness tester, (Model-FM-7- Japan), was used to measure Vickers hardness values of used alloys. Internal friction $\mathrm{Q}^{-1}$ and the elastic constants of used alloys were determined using the dynamic resonance method [12-14]. 
Volume 4 Issue 4, 2015, ISSN-2319-7560 (Online)

\section{RESULTS AND DISCUSSIONS}

\section{Microstructure}

X-ray diffraction patterns of $\operatorname{Sn}_{91-x} Z_{9} \operatorname{In}_{x}(x=0,1,2,3,4,5$ wt. \%) rapidly solidified alloys show that sharp lines of body centered tetragonal $\mathrm{Sn}$ and hexagonal $\mathrm{Zn}$ phases as presented in Figure 1. From $\mathrm{x}$-ray analysis, adding In content to $\mathrm{SnZn}$ 9 alloy produced a change in its matrix microstructure (lattice parameters, unit cell volume and crystal size) and the shape of formed phases such as peak intensity, peak broadness and peak position. That is because In atoms dissolved in $\mathrm{Sn}_{91} \mathrm{Zn}_{9}$ matrix formed a solid solutionlor and some In atoms formed a traces of undetected phases (In or In intermetallic phases). Also the calculated lattice parameters, (a and c), unit volume cell and crystal size of tetragonal tin phase in $\mathrm{Sn}_{91-\mathrm{x}} \mathrm{Zn}_{9} \operatorname{In}_{\mathrm{x}}(\mathrm{x}=0,1,2,3,4,5$ wt. \%) alloys are listed in Table 1. The results illustrated that, adding In content to $\mathrm{Sn}_{91} \mathrm{Zn}_{9}$ alloy caused a little variation in lattice parameters and unit cell volume with a significant variation in crystal size of tetragonal tin phase of $\mathrm{Sn}_{91} \mathrm{Zn}_{9}$ alloy after adding In content.
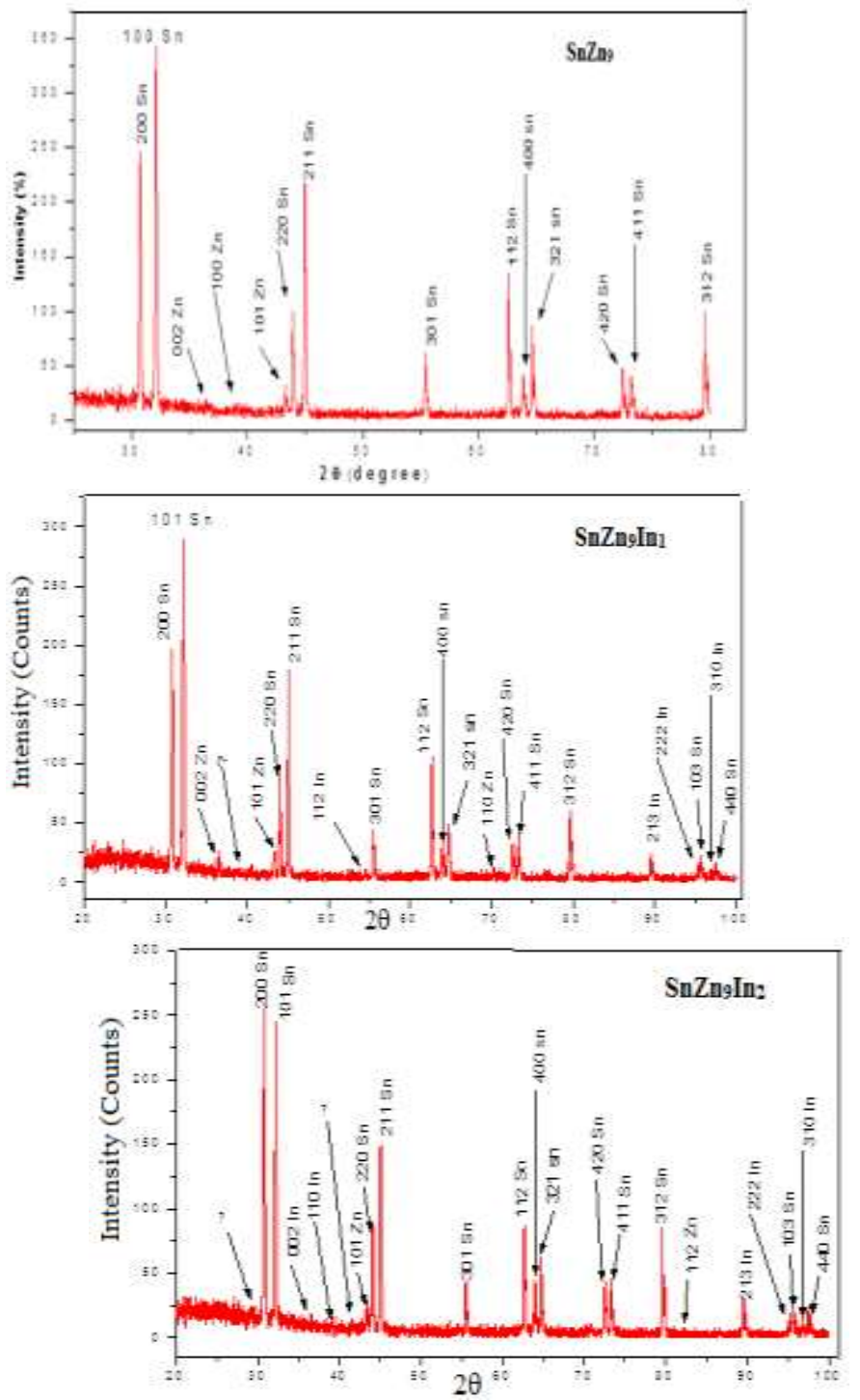
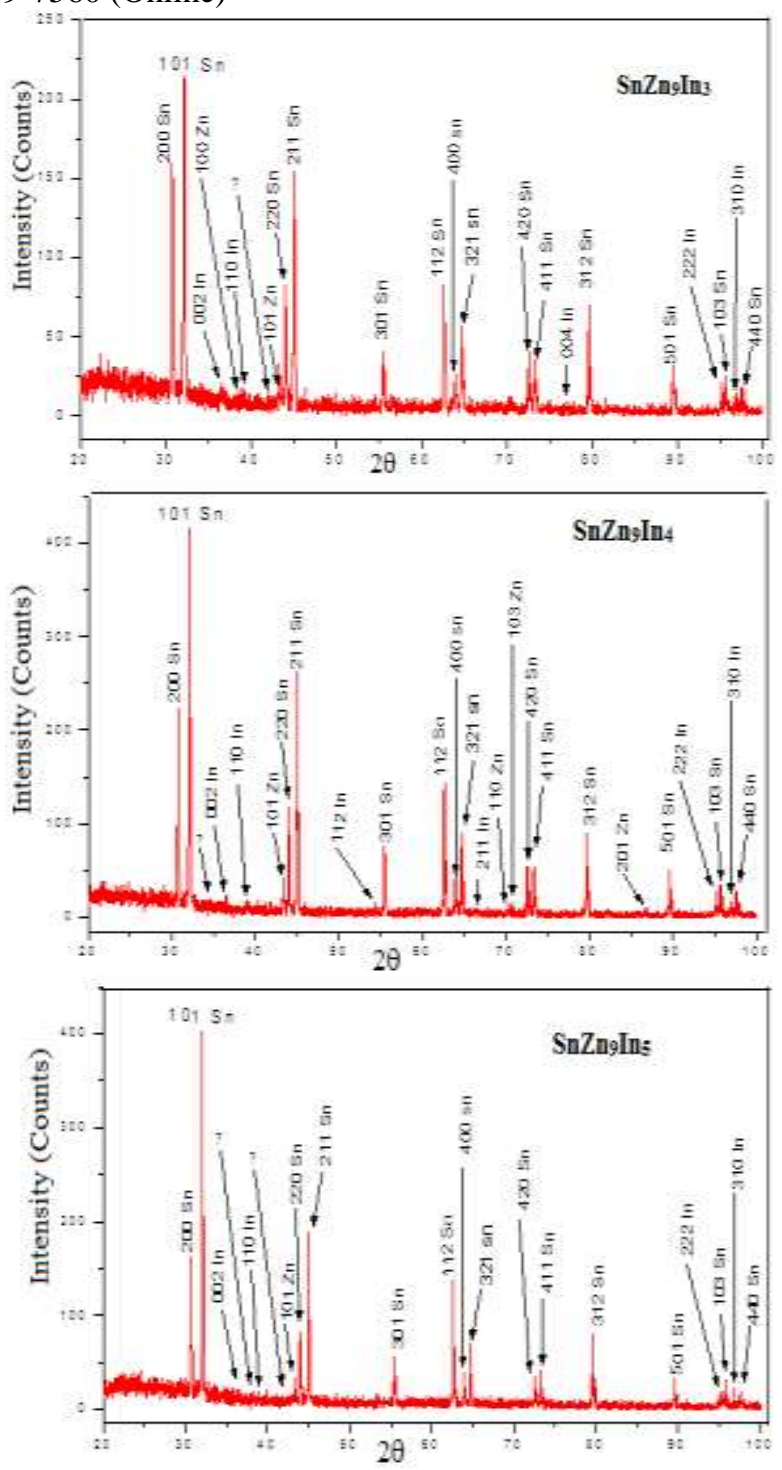

Figure 1:- X-ray diffraction patterns of $\mathrm{Sn}_{91-\mathrm{x}} \mathrm{Zn}_{9} \mathrm{In}_{\mathrm{x}}$ alloys

Table 1:-lattice parameters, unit cell volume and crystal particle size of $\beta$-Sn in $\mathrm{Sn}_{91-\mathrm{x}} \mathrm{Zn}_{9} \mathrm{In}_{\mathrm{x}}$ alloys

\begin{tabular}{|c|c|c|c|c|}
\hline Samples & a $\AA$ & c $\AA$ & $\mathrm{V}^{3}$ & $\tau \AA$ \\
\hline SnZn $_{9}$ & 5.82 & 3.183 & 107.83 & 681.943 \\
\hline SnZn $_{9} I_{1}$ & 5.801 & 3.182 & 107.11 & 454.054 \\
\hline SnZn $_{9} I_{2}$ & 5.805 & 3.188 & 107.45 & 465.097 \\
\hline SnZn $_{9} I_{3}$ & 5.814 & 3.189 & 107.78 & 707.90 \\
\hline SnZn $_{9} I_{4}$ & 5.812 & 3.189 & 107.70 & 593.691 \\
\hline SnZn $_{9} I_{5}$ & 5.821 & 3.180 & 107.76 & 658.568 \\
\hline
\end{tabular}


International Journal of Science and Engineering Applications

Volume 4 Issue 4, 2015, ISSN-2319-7560 (Online)

Scanning electron micrographs, SEM, of $\mathrm{Sn}_{91-\mathrm{x}} \mathrm{Zn}_{9} \operatorname{In}_{\mathrm{x}}(\mathrm{x}=0,1,2,3,4$, 5 wt. \%) alloys show heterogeneous structure (different features) as seen in Figure 2 and it's agreed with $\mathrm{x}$-ray analysis.

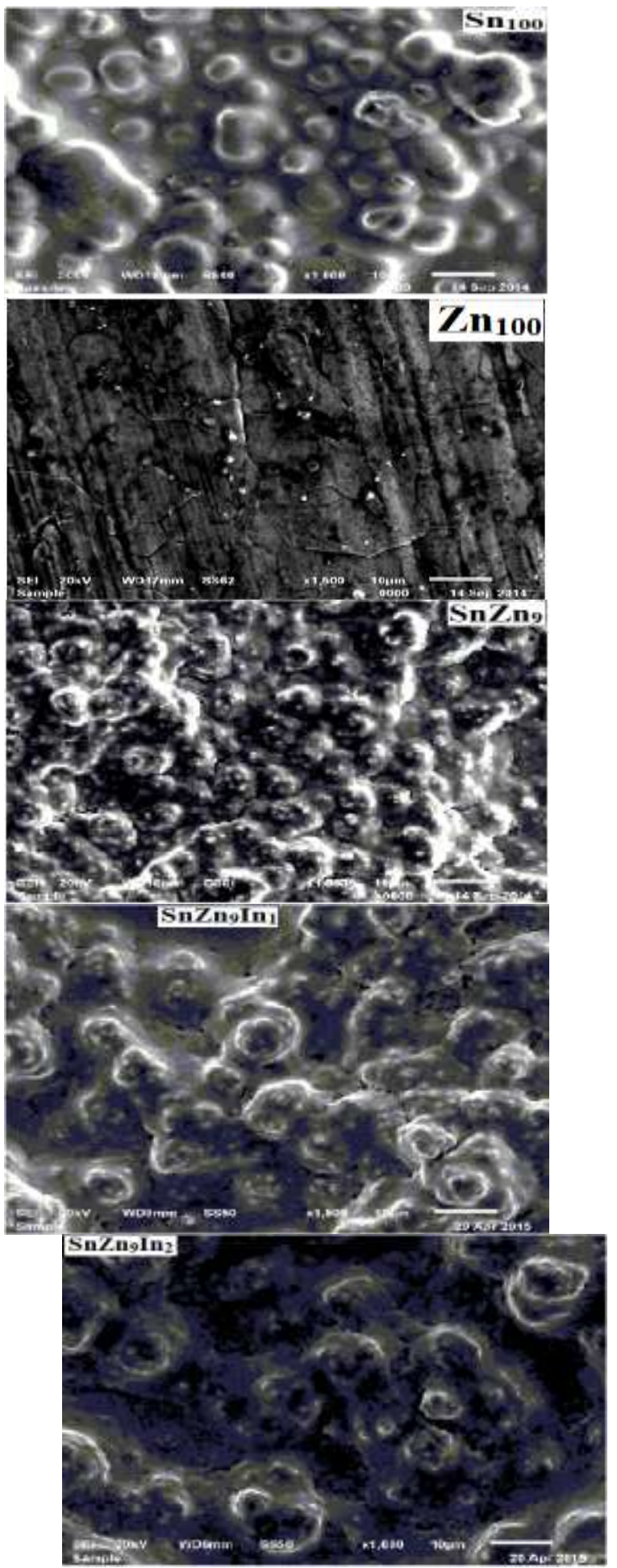

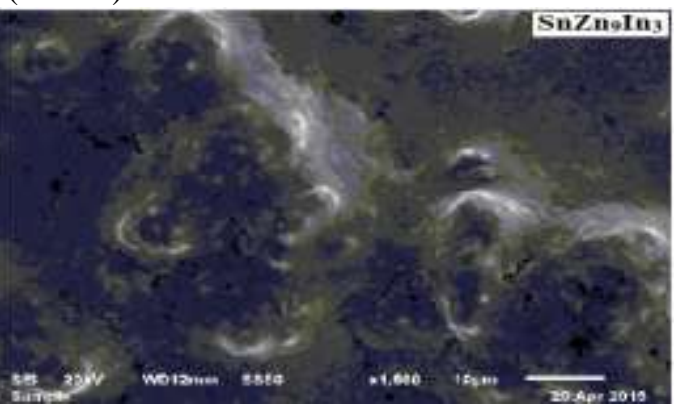
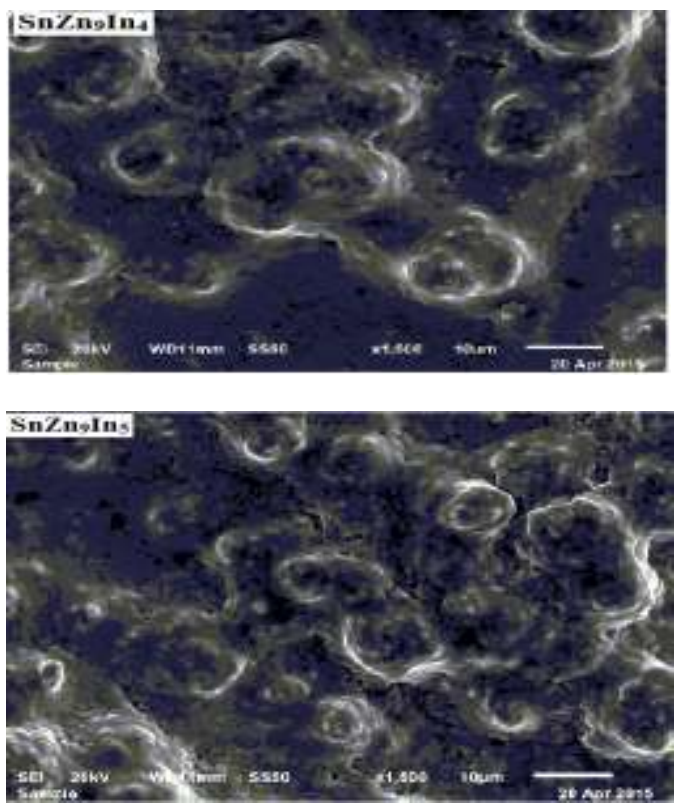

Figure 2:- SEM of $\mathrm{Sn}_{91-\mathrm{x}} \mathrm{Zn}_{9} \mathrm{In}_{\mathrm{x}}$ alloys

\section{Soldering properties}

Wettability

Wettability is quantitatively evaluated by the contact angle formed at the solder substrate's flux triple point. The contact angles of $\mathrm{Sn}_{91-\mathrm{x}} \mathrm{Zn}_{9} \mathrm{In}_{\mathrm{x}}(\mathrm{x}=0,1,2,3,4,5$ wt. \%) alloys on $\mathrm{Cu}$ substrate in air are shown in Table 2. The results show that, the contact angle of $\mathrm{Sn}_{91} \mathrm{Zn}_{9}$ alloy is variable decreased after adding In content. The $\mathrm{Sn}_{86} \mathrm{Zn}_{9} \mathrm{In}_{5}$ alloy has low contact angle value and also adequate for solder applications.

Table 2:-contact angles of $\mathrm{Sn}_{91-\mathrm{x}} \mathrm{Zn}_{9} \mathrm{In}_{\mathrm{x}}$ alloys

\begin{tabular}{|c|c|}
\hline Samples & Contact angle $\left(\theta^{\circ}\right)$ \\
\hline SnZn $_{9}$ & 46 \\
\hline SnZn$_{9} I_{1}$ & 42.5 \\
\hline SnZn$_{9} I_{2}$ & 45.75 \\
\hline SnZn $_{9} I_{3}$ & 45 \\
\hline SnZn $_{9} I_{4}$ & 42 \\
\hline SnZn $_{9} I_{5}$ & 38.25 \\
\hline
\end{tabular}




\section{Thermal properties}

The amounts of thermal properties depend on the nature of solid phase and on its temperature. The DSC thermographs were achieved with heating rate $10{ }^{\circ} \mathrm{C} / \mathrm{min}$ in the temperature range $0-400$ ${ }^{\circ} \mathrm{C}$. The DSC thermographs of $\operatorname{Sn}_{91-\mathrm{x}} \mathrm{Zn}_{9} \operatorname{In}_{\mathrm{x}}(\mathrm{x}=0,1,2,3,4,5$ wt. \%) alloys are shown in Figure 3. From these graphs the melting point, pasty range and other thermal parameters (specific heat, $C_{p}$, enthalpy, $\Delta \mathrm{H}$, entropy, $\Delta \mathrm{S})$ of $\mathrm{Sn}_{91-\mathrm{x}} \mathrm{Zn}_{9} \operatorname{In}_{\mathrm{x}}(\mathrm{x}=0,1,2,3,4,5 \mathrm{wt}$. \%) alloys are identified and then listed in Table 3. A little variation occurred in thermo-graph (Endo-thermal peaks) of $\mathrm{Sn}_{91} \mathrm{Zn}_{9}$ alloy after adding indium. That is because In atoms dissolved in matrix alloy changed its structure and that is agreed with $\mathrm{x}$-ray diffraction analysis. The melting temperature of $\mathrm{Sn}_{91} \mathrm{Zn}$ 9 alloy decreased after adding indium content. Also the pasty range and other thermal parameters of $\mathrm{Sn}_{91} \mathrm{Zn}_{9}$ alloy varied after adding indium content.
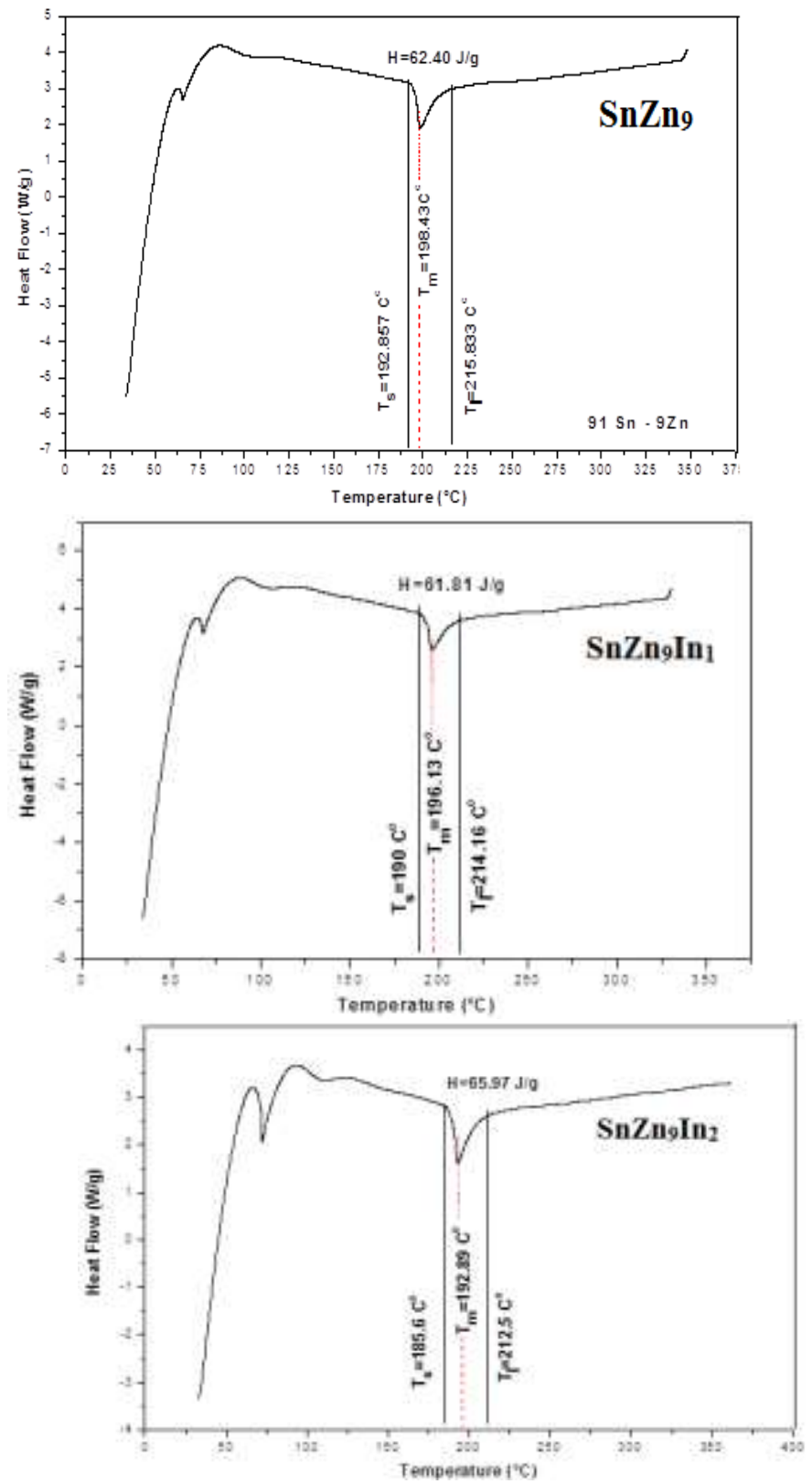
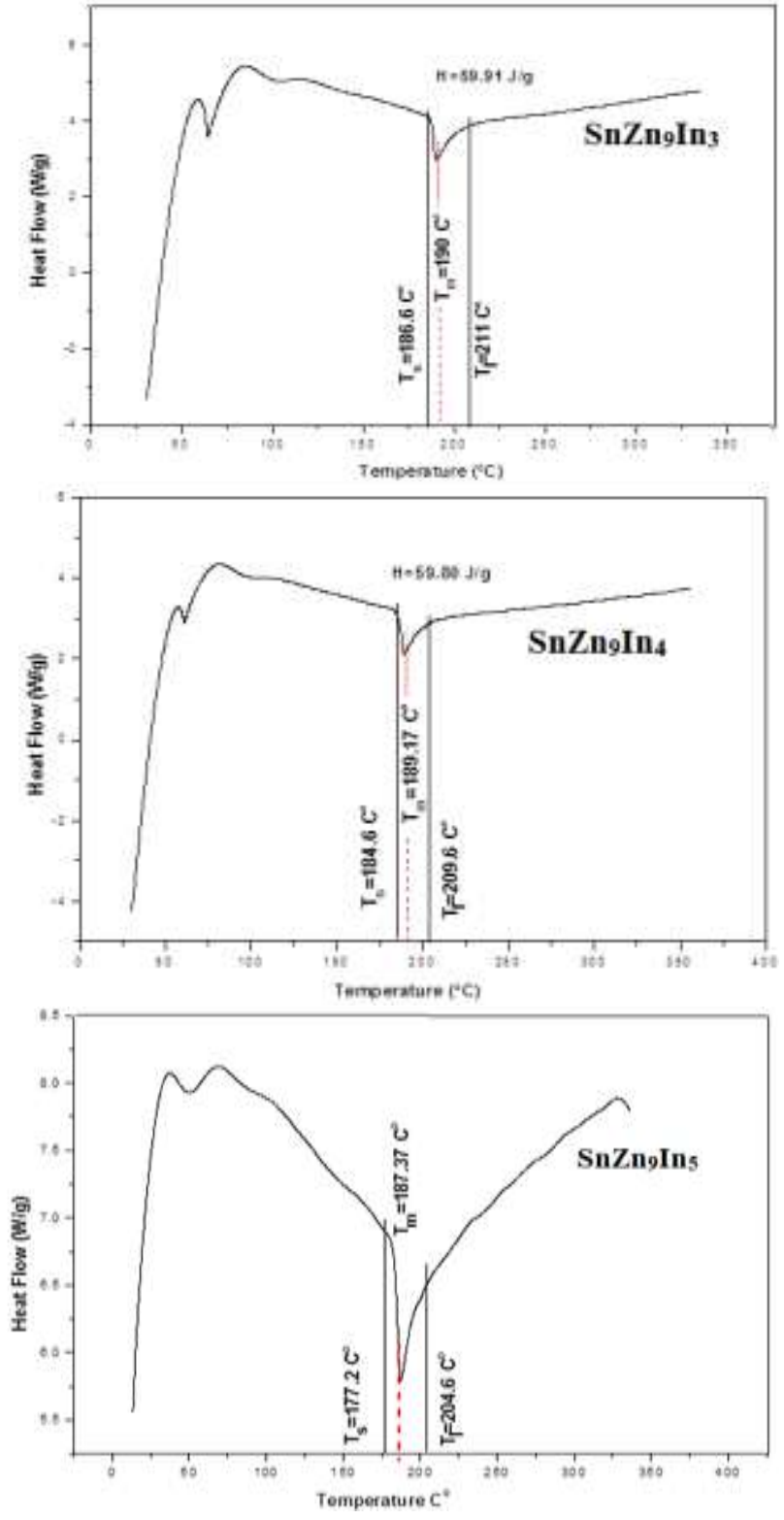

Figure 3:- DSC graphs of $\mathrm{Sn}_{91-\mathrm{x}} \mathrm{Zn}_{9} \mathrm{Al}_{\mathrm{x}}$ alloys
Table 3:- melting point and other thermal parameters of $\mathrm{Sn}_{91-\mathrm{x}} \mathrm{Zn}_{9} \mathrm{Al}_{\mathrm{x}}$ alloys

\begin{tabular}{|c|c|c|c|c|}
\hline Samples & $\begin{array}{c}\text { Melting } \\
\text { point }^{\circ} \mathrm{K}\end{array}$ & $\begin{array}{c}\mathrm{CP}_{\mathrm{P}} \\
\mathrm{J} / \mathrm{g} .{ }^{\circ} \mathrm{K}\end{array}$ & $\begin{array}{c}\Delta \mathrm{S} \\
\mathrm{J} / \mathrm{g} .{ }^{\circ} \mathrm{K}\end{array}$ & $\begin{array}{c}\Delta \mathrm{H} \\
\mathrm{J} / \mathrm{g}\end{array}$ \\
\hline $\mathrm{SnZn}_{9}$ & 471.43 & 2.716 & 130.772 & 62.40 \\
\hline $\mathrm{SnZn}_{9} \mathrm{In}_{1}$ & 469.13 & 2.558 & 130.155 & 61.81 \\
\hline $\mathrm{SnZn}_{9} \mathrm{In}_{2}$ & 465.89 & 2.45 & 139.889 & 65.97 \\
\hline $\mathrm{SnZn}_{9} \mathrm{In}_{3}$ & 463.12 & 2.46 & 127.025 & 59.91 \\
\hline $\mathrm{SnZn}_{9} \mathrm{In}_{4}$ & 462.17 & 2.392 & 127.256 & 59.80 \\
\hline $\mathrm{SnZn}_{9} \mathrm{In}_{5}$ & 460.37 & 2.271 & 151.858 & 71.45 \\
\hline
\end{tabular}




\section{Electrical resistivity}

Crystalline imperfections and plastic deformation raises the electrical resistivity as a result of the increased number of electron scattering centers. The measured electrical resistivity of $\mathrm{Sn}_{91-\mathrm{x}} \mathrm{Zn}_{9} \operatorname{In}_{\mathrm{x}}(\mathrm{x}=0,1,2,3,4,5$ wt. \%) alloys at room temperature using double bridge method are shown in Table 4. Electrical resistivity of $\mathrm{Sn}_{91} \mathrm{Zn}_{9}$ alloy variable increased after adding indium content. That is because indium atoms dissolved in the $\mathrm{Sn}_{91} \mathrm{Zn}_{9}$ matrix, formed solid solution/or and some traces, played as scattering center for conduction electrons increased electrical resistivity value.

Table 4:- electrical resistivity of $\mathrm{Sn}_{91-\mathrm{x}} \mathrm{Zn}_{9} \mathrm{In}_{\mathrm{x}}$ alloys

\begin{tabular}{|c|c|}
\hline Samples & $\rho \times 10^{-8} \Omega . m$ \\
\hline SnZn $_{9}$ & 33.65 \\
\hline SnZn$_{9} I_{1}$ & 35.6 \\
\hline SnZn$_{9} I_{2}$ & 39.94 \\
\hline SnZn$_{9} I_{3}$ & 40.83 \\
\hline SnZn$_{9} I_{4}$ & 38.27 \\
\hline SnZn$_{9} I_{5}$ & 39.39 \\
\hline
\end{tabular}

\section{Mechanical properties}

Elastic moduli

The elastic constants are directly related to atomic bonding and structure. It is also related to the atomic density. The measured elastic modulus and calculated bulk modulus, B, and shear modulus, $\mu$, of $\mathrm{Sn}_{91-\mathrm{x}} \mathrm{Zn}_{9} \operatorname{In}_{\mathrm{x}}(\mathrm{x}=0,1,2,3,4,5$ wt. \%) alloys are listed in Table 5. Elastic modulus value of $\mathrm{Sn}_{91} \mathrm{Zn}_{9}$ alloy is variable decreased after adding indium content as shown in Table 5. That is because the dissolved indium atoms, formed solid solution $\backslash$ or stick on grain boundary/ or formed small cluster from phases in Sn91Zn9 matrix, affected on bond matrix strengthens.

\section{Internal friction and thermal diffusivity}

Internal friction is a useful tool for the study of structural aspects of alloys. Resonance curves of $\mathrm{Sn}_{91-\mathrm{x}} \mathrm{Zn}_{9} \mathrm{In}_{\mathrm{x}}(\mathrm{x}=0,1,2,3,4,5$ wt. \%) alloys are shown in Figure 4 and the calculated internal friction values are presented in Table 5. Also from resonance frequency at which the peak damping occur using the dynamic resonance method the thermal diffusivity value was calculated and then listed in Table 5. The results show that, internal friction value of $\mathrm{Sn}_{91} \mathrm{Zn}_{9}$ alloy is variable decreased by adding indium content.

Table 5:- elastic moduli, internal friction and thermal diffusivity of $\mathrm{Sn}_{91-\mathrm{x}} \mathrm{Zn}_{9} \mathrm{In}_{\mathrm{x}}$ alloys

\begin{tabular}{|c|c|c|c|c|c|}
\hline Samples & E GPa & $\begin{array}{c}\mu \\
\mathrm{GPa}\end{array}$ & $\begin{array}{c}\mathrm{B} \\
\mathrm{GPa}\end{array}$ & $\mathrm{Q}^{-1}$ & $\begin{array}{c}\mathrm{D}_{\text {th }} \times 10^{-7} \\
\mathrm{~m}^{2} \backslash \mathrm{sec}\end{array}$ \\
\hline SnZn$_{9}$ & $44.34 \pm 3.1$ & 16.42 & 49.30 & 0.085 & 4.476 \\
\hline SnZn$_{9} \mathrm{In}_{1}$ & $30.75 \pm 1.2$ & 11.39 & 34.05 & 0.052 & 3.392 \\
\hline SnZn$_{9} \mathrm{In}_{2}$ & $29.53 \pm 1.2$ & 10.95 & 32.57 & 0.054 & 2.947 \\
\hline SnZn$_{9} \mathrm{In}_{3}$ & $33.04 \pm 2.1$ & 12.25 & 36.3 & 0.081 & 3.484 \\
\hline SnZn$_{9} \mathrm{In}_{4}$ & $32.9 \pm 2.19$ & 12.20 & 35.99 & 0.057 & 2.773 \\
\hline SnZn9In & $30.09 \pm 1.6$ & 11.17 & 32.80 & 0.059 & 2.316 \\
\hline
\end{tabular}

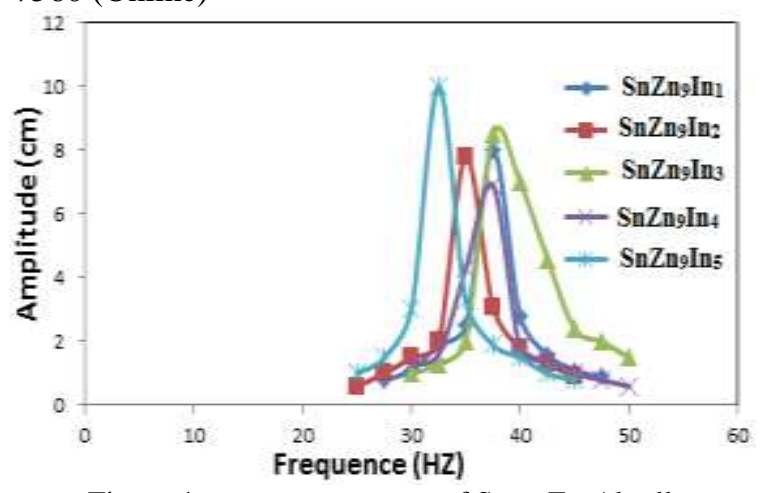

Figure 4:- resonance curves of $\mathrm{Sn}_{91-\mathrm{x}} \mathrm{Zn}_{9} \mathrm{Al}_{\mathrm{x}}$ alloys

Vickers microhardness and minimum shear stress

The hardness is the property of material, which gives it the ability to resist being permanently deformed when a load is applied. The greater of material hardness is the greatest of the resistance to deformation. The Vickers hardness number of $\operatorname{Sn}_{91-x} Z_{9} \operatorname{In}_{x}(x=0,1$, $2,3,4,5$ wt. \%) alloys at 10 gram force and indentation time $5 \mathrm{sec}$ are shown in Table 6. Also calculated minimum shear stress of Sn91${ }_{x} \mathrm{Zn}_{9} \operatorname{In}_{x}(x=0,1,2,3,4,5$ wt. \%) alloys are listed in Table 6. Vickers hardness value of $\mathrm{Sn}_{91} \mathrm{Zn}_{9}$ alloy is variable increased by adding indium content.

Table 6:- Vickers hardness and minimum shear stress of $\mathrm{Sn}_{91-\mathrm{x}} \mathrm{Zn}_{9} \mathrm{In}_{\mathrm{x}}$ alloys

\begin{tabular}{|c|c|c|}
\hline Alloys & $\mathrm{H}_{\mathrm{v}} \mathrm{kg} / \mathrm{mm}^{2}$ & $\mu_{\mathrm{n}} \mathrm{kg} / \mathrm{mm}^{2}$ \\
\hline SnZn 9 & $22.75 \pm 1.1$ & 7.508 \\
\hline SnZn$_{9} I_{1}$ & $23.53 \pm 1$ & 7.766 \\
\hline SnZn$_{9} I_{2}$ & $27.8 \pm 1.23$ & 9.174 \\
\hline SnZn$_{9} I_{3}$ & $30.7 \pm 1.9$ & 10.131 \\
\hline SnZn $_{9} I_{4}$ & $26.37 \pm 1.2$ & 8.701 \\
\hline SnZn $9 I_{5}$ & $36.82 \pm 2.5$ & 12.149 \\
\hline
\end{tabular}

\section{CONCLUSIONS}

1. Adding indium content to $\mathrm{SnZn}$ 9 alloy produced a change in its matrix microstructure (lattice parameters, unit cell volume and crystal size) and the shape of formed phases

2. The contact angle, melting temperature, elastic modulus and internal friction values of $\mathrm{SnZn} 9$ alloy are variable decreased after adding indium content. The SnZn ${ }_{9} \mathrm{In}_{5}$ alloy has low contact angle and melting point values.

3. The electrical resistivity and Vickers hardness values of SnZn9 alloy are variable increased after adding indium content.

4. The $\mathrm{SnZn}_{9} \mathrm{In}_{5}$ alloy has adequate properties for solder applications

\section{REFERENCES}

[1] Shiue R. K, Tsay L. W, Lin C. L and Ou J. L, J. Mater. Sci. 38 (2003) 1269

[2] Miiyamoto A, Ogawa T and Ohsawa T, Mater. Sci. Res. Inter. 9 (2003) 16

[3] Ohoka T, Nakamura Y, Ono T, J. Mater. Sci. 39 (2004) 4379

[4] Kim K.S, Yang J.M, Yu C.H, Jung I.O, Kim H. H, J. Alloy. 
Compd. 379 (2004) 314

International Journal of Science and Engineering Applications Volume 4 Issue 4, 2015, ISSN-2319-7560 (Online)

[5] Anderson I. E, Foley J. C, Cook B. A, Harringa J, Terpstra

R. L, Unal O, J. Electron. Mater. 30: 9 (2001) 1050

[6] McCormack M, Jin S, Kammlott G. W, Chen H. S, Appl. Phys. Lett. 63: 1 (1993) 15

[7] Miric A. Z, Grusd A, Surf. Mount Technol. 10: 1 (1998) 19

[8] Lin K. L, Hsing L and Liu T. P, J. electronic materials, 27: 3(1998) 97

[9] Lin K. I and Lin K. L, J. of Electron. Mater. 31:8 (2002) 861

[10] Chen K. I, Cheng S. C, Wu S and Lin K. L, J. alloy. Compd. 416 (2006) 98

[11] Das S. K, Sharif A, Chana Y. C, Wongc N. B and Yung W. K. C, J. Alloy. Compd. 481 (2009) 167

[12] Cullity B. D, "Element of x-ray diffraction" Ch.10 (1959) 297

[13] Sppinert S and Teffit W. E, ASTM, Proc. 61 (1961) 1221

[14] Schreiber E, Anderson O. L and Soga N, Elastic Constants and their Measurement, McGraw-Hill Book Company, Ch. 4 (1973) 